\title{
Recovering Oral Motor Strength to Protect Children from Severe Cerebral Palsy through Virtual Gaming Technology
}

\author{
Vinay Kumar Pandey, Vinayak Majhi , Sudip Paul
}

\begin{abstract}
Recent methods and advancing world of medical electronics changed lots of traditional therapeutic intervention and approach for the management and treatment of several disorders. In the same line of approach the way of treatment of cerebral palsy is also changing more or less with recent advancement in clinical research. These clinical research and advancement gives a new pathway in the understanding of $\mathrm{CP}$, early detection and prevention with primary care. This provides us a new opportunity to treat $C P$ with the combination of both modern approach as well as the traditional therapeutic approach. Implementation of modern therapeutic electronics with enriched environment plays a vital role in treatment and management of CP. This paper provides a comparative study of mild and severely disabled children kept in different environment of treatment in the different geographical regions of the country i.e. India.

The child and therapist both are much interested and enjoy a lot when such types of therapy is given from modern devices like computer, tablet, mobile phones in the form of interactive gaming to achieve a variety of therapeutic goals. Use of electronic and software gaming specifically designed for therapeutic purposes may adjunct to manual therapy. These games in recovery of oral motor strength in rehabilitation settings are showing more enjoyable and acceptable for growing children and adults too.
\end{abstract}

Keywords: Cerebral Palsy, Treatment, Management, Therapeutic, Environment.

\section{INTRODUCTION}

The brain is plastic in nature and can be molded in some extent as per requirement that signifies the neurons are also plastic in nature; hence, both can be molded as it is required for normal way of living and they also changes with stimulus and experience, therapy and the working environment (1). Environmental enrichment affect more than the normal environment in brain stimulation and modulation. The brain plasticity varies with time as a child grows, neuronal connections are more in early childhood and as time passes

Revised Manuscript Received on December 30, 2019.

* Correspondence Author

Vinay Kumar Pandey, Department of Biomedical Engineering, School of Technology, North Eastern Hill University, Shillong, Meghalaya, India. Email: ervinaypandeyec@gmail.com

Vinayak Majhi, Department of Biomedical Engineering, School of Technology, North Eastern Hill University, Shillong, Meghalaya, India Email: Majhi.vinayak@gmail.com

Sudip Paul*, Department of Biomedical Engineering, School of Technology, North Eastern Hill University, Shillong, Meghalaya, India Email: Sudip.paul.bhu@gmail.com

(C) The Authors. Published by Blue Eyes Intelligence Engineering and Sciences Publication (BEIESP). This is an open access article under the CC BY-NC-ND license (http://creativecommons.org/licenses/by-nc-nd/4.0/) some neuronal connections become stronger and some becomes very weak and later they disappear. Depends upon the usability of neuronal circuitry they grow themselves as weak, strong, active and inactive. Experience induced changes can be seen as when a child got birth at that time the brain circuit is diverse and is much more complex and it reduces a little at adulthood. By utilizing the property of neural plasticity we can bring a mild condition patient into normal condition through the activation of various synaptic links via stimulation (Electrical, magnetic or therapeutic) (2). The effect of early intervention is well established and well-known. From the perspective of speech and feeding dysfunctions in children with cerebral palsy, many of the children face the challenge to be accepted at school and in public gathering owing to the drooling and spill during feeding. This is initial stage of isolation from society. It become severe if no action is to be taken to get inclusion in the same age group children. This leads a need for cranial nerve stimulation exercises to be done regularly even to an extent of three to five times a day. The same is often forced upon the child, there is a need to develop a set of cranial nerve exercises and link up the motor movements e.g. movement of tongue, cheek, jaw etc. with the computer in a game format. This will help the child to do it actively regularly and with interest.

Synaptic connection and strength in child's brain is directly proportional to the usability (3). If a synaptic network is used more frequently then it will become stronger than the rarely used connection. Neuronal transmissions from frequently used and stronger connection are fast and efficient than the weaker connections (4). Thus exposure to various therapeutic activities and experiences may improve muscle strength and signal transmission to and fro from central nervous system and peripheral nervous system. This also utilizes the neural plasticity characteristic of our brain. Early yoga and physiotherapeutic activities are having the potential of healing the small disturbances and can bring movement and strength in sensory and motor connections. Early intervention can prevent from secondary deformities like muscle stiffness and contracture that are caused by soft tissues. Without these early interventions the child may suffer from severe cerebral palsy at later stage that may or may not be curable. These interventions may reinforce neuronal synaptic connections and can be helpful in effective, efficient and controlled movement of various body parts (5). Overall it may give freedom to the individual in daily living by providing appropriate muscle strength for proper functioning. Regular and repetitive physiotherapeutic exercises can build strong neuronal network leading to good communicative skills and healthy individual.

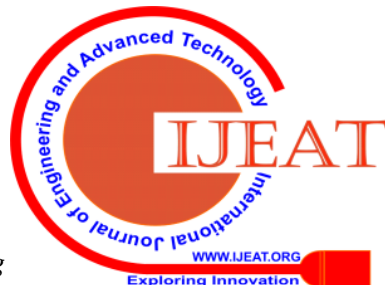




\section{A. Goals of Early Therapeutic Interventions}

- Improve Respiratory function

- Improve muscle strength

- Improve motor control and coordination

- Improve range of motion (Degree of freedom)

- Preserve muscle strength and joint flexibility

\section{B. Improve Respiratory function}

Life expectancy has been improved from last few decades all over the world. Specifically aging and related problems are primarily caused by poor degradation of lung functionality occurs due to the improper functioning respiratory muscles and decreased thoracic motility along with diminished pulmonary function efficiency (6). There are profound changes occurs at old age associated with cardiovascular system consisting of changes in heart rate variability (HRV) and spontaneous baroreflex gain. These changes result in poor adaptation and control of various functionalities like cardiorespiratory systems, cardiovascular system etc. These characteristic changes of natural aging process may lead to reduced life expectancy and reduced quality of life. plays important role in proper functioning of various body organs. Breathing exercises are having direct impact on brain functioning and also on respiratory systems (7). It can recover blunt sympathetic excitatory pathways by repetitive and regular practice. These practices are simple, cost effective intervention technique, easy to learn and can be practiced in regular routine within home premises resulting beneficial in respiratory and cardiovascular systems for both young aged people and also for old aged people. Kapalbhati and Bhastrika pranayams are exclusively and comprehensibly breathing/respiratory yoga exercises include exhalation and inhalation (8). Bhastrika pranayama makes balance in vata, pitta and kapha. This technique is well known to generate heat in the body by engaging chest and lungs. There are several benefits of Bhastrika like brain oxygenation, good for nervous and motor systems, energizes the body and mind, reduces anxiety and depression, helps in fibrosis, strengthen immunity etc.

\section{Improve muscle strength}

When we say about muscle strengthening exercises, people think that it is required to body builders and sports person. There is much ignorance that it is required to the person having locomotors disability and to the disable population. These exercises are much needed to the disabled people than the body builders and sportsman to live comfortable life. A person having arm paralysis or leg paralysis uses walking aids in the form of wheel chair either manual or automatic. Even though if a disabled person wants to move himself with wheelchairs, he requires strengthened arm to shift from one place to another place. Such type of paralysis occurs due to many factors like developmental delay, malnutrition, decreased bone density etc. (9). These problems can be tackled by various muscle strengthening exercises. In fact, muscle strengthening exercises can build neuronal connection and also can increase bone density. Muscle strength training is having no importance after a certain level and also it is not having any importance be a threshold value. Strengthening above threshold value are having great importance in terms of functional recovery and day to day living by improving present performance at functional
It has been seen from ancient days that breathing exercises

activity levels. The functional activities that are commonly addressed are siting, standing, walking, stair climbing, balancing in straight and curved positions. Independence in siting and standing maneuvers are much needed physical component related with weight transfer and knee extension force (10). In some cases people use their hands in sitting and standing processes. Although knee extensors strength on each side can be correlated along with body weight in sit to stand procedure.

\section{Improve motor control and coordination}

People having difficulties in performing fine and gross motor skills are seeing lacking everywhere in terms of performance either in classroom or in day to day living. The level of sensory and motor skill level below age specific level can degrade academic and interpersonal skills. Additionally, several comorbid problems have been seen in these people like social isolation, low confidence, behavioral problems etc. (11). Therapeutic approaches that are dealing to overcome such disabilities can be grouped into three categories as conventional physical therapy, process oriented and task oriented. One more grouping that can be added may be patient centric and individualized depends on specific symptoms and etiology. These exercises are specifically prescribed to correct impairment, restoring functional activities, improve musculoskeletal strength and maintaining art of physical well-being. These exercises can be specific and patient oriented or it can be general and vigorous to regain functional activity. There is a strong connection among therapy and physical well-being as studies showed that engaging at any level of exercise in a disciplined manner is always beneficial in improving motor function and mobility (12). Physician and physiotherapist can improve mobility of a disease by combining medicine and physical exercises to improve thinking, cognition, memory and reduced risk of falls.

\section{E. Improve range of motion (Degree of freedom)}

Decreased range of motion can restrict the degree of freedom of a person. Flexible hand, leg, knee and joints can impact functional efficiency and gaming capability of human being. In this way to provide treatment to a loss of movement, physical exercises are necessary for efficient movement. Degree of freedom can be viewed as the amount of joint range of motion (ROM) and flexibility is known as degree of extensibility of connective tissues. There are various factors that can limit ROM and flexibility of arm, leg, shoulder, knee etc. (13). These factors may include joint effusion, tissue structure, bone architecture and alignment of articular surfaces. Other factors that can affect are muscles and their tendons, skin, adipose tissues and neural tissues. All these factors basically involved in restriction of basic three types of movement

\section{F. Preserve muscle strength and joint flexibility}

In our body joints are connected with ligament and combination of muscle with it provides stability. It is having layered tissues of articular cartilage at the terminal sections of bones providing great help in compression and expansion of muscles during our movement. 
Healthy joints are symbol of perfect cartilage to support active lifestyle and daily activities including sport and exercise (14)

Exercise plays a big role in keeping joints healthy with strong muscle strength. Due to the lack of flexibility in movement of different joints and inappropriate muscle strength a person may not be able to perform daily activities like sitting, bending, standing, movement etc. Different exercises can tackle such type of problems without having any side effects.

\section{METHODOLOGY}

\section{A. Stage I: Selection of nerve stimulation activities converted in gaming format-}

There is twelve pair of cranial nerves which are involved in speech, language, swallowing, hearing, vision and all other motor and sensory activities of mouth and head. These nerves are of great importance for speech language pathologist as they are directly link brain with our oral musculature like head, neck and trunk. Out of the 12 pairs, six pairs are of more focused on speech, swallowing, pharynx, larynx and other (including special senses like taste, hearing and sensation) oral motor functions (15). All these pairs of muscles some are motor muscles or sensory muscles or mixed kind of muscles which are involved in either motor function or sensory function or in both. Functional ability of a person is dependent on the oral musculature and nerve ability including the neuronal circuitry. Jaw pressure, blowing strength, biting force and other parameters define how much a person is capable in performing daily activities. The description and name of cranial nerves are based on their location of origin and their types are as given below:

Olfactory-I: It is special nerve of smell or olfaction of food and beverages. It consists of olfactory bulb, epithelium and rhinencephalon expanded up to mucous membrane via nasal cavity through olfactory region (16). It acts as a chemical sensor in detection various flavors and also plays an important role in nutrition and safety. Smell and taste sensation are transmitted through special visceral afferent fibers. The dysfunction of olfactory nerve leads to anosmia, dysosmia, cacosmia, phantosmia, hyperosmia, agnosia and other smell and odor related disorders.

Optic-II: Optic nerve processes visual stimulus through special somatic afferent fibers. Photo sensation enters to retina via photoreceptors rod and cones. This electrical signal is transmitted to other cells in order to process and integrate motor and sensory information (Mainly Sensory). This photoreceptor sends electrical signal to the ganglion neurons residing retinal region.

Oculomotor-III: This plays an important role in tracking, controlling and movement involving somatic motor component part of CN III.

Trochlear-IV: It is one among motor nerves. Its anatomy is basically divided into four parts consisting of nucleus and an intraparenchymal portion, cisternal portion, cavernous sinus portion, orbital portion.

Trigeminal-V: It is responsible for transmitting sensation from face to brain and brain to mouth, teeth, face and nasal cavity. It controls the muscle used for chewing and biting. Due to improper functioning of $\mathrm{CN} \mathrm{V}$, inadequate jaw pressure, jaw deviation, can't differentiate sensation of sharp and dull objects at face, can't differentiate sensation of cold and warm objects and can't differentiate sensation of soft touch.

Abducens-VI: It originates from abducens nuclei in the pons region of human brain. This comes under the category of somatic nerve performing motor functions of lateral rectus muscle. The lateral rectus attaches to the anterolateral part of sclera.

Facial-VII: It controls the muscle of facial expression and provides taste sensation from anterior of tongue, pressure sensation of face. Dysfunction of CN VII may cause problems in corneal reflex, eyelid closure, smile, lip movements, nasal movements, puffing of cheeks, chin movements and assisting grimace.

Vestibulocochlear-VIII: Its functions are related to hearing, balance and eye movement. Head movement coordinated with eye movement, total body movements and balance tasks, habituation exercises for vestibular system adaptation, relaxation exercises, aerobic dancing and step program to reduce balance and coordination deficits.

Glossopharyngeal-IX: It provides information for the gag reflex, taste sensation, parasympathetic innervations to parotid gland, innervates the stylopharyngeus muscle of the pharynx that elevates the larynx during swallowing, provides sensory innervations to middle ear and internal surface of the tympanic membrane and Eustachian tube.

Vagus-X: Functions of vagus nerve are speech, voice, gag reflex, swallowing, phonation, involuntary muscle and gland control, visceral sensibility, taste and cutaneous sensibility. Vagus nerve can be activated through swallow maneuvers (effortful swallow, chin tuck, supra glottic swallow), breathing exercises, articulation drill, reading task, lower chin rotation, jaw up down movement, tongue rotation and folding inside, lip massage and sucking.

Accessory-XI: Functional activities of CN XI are shoulder shrugging, head neck movement. Slugging and upholding, protraction and retraction, elevation and depression and transcutaneous are the nerve stimulation exercises that can recover its functionality.

Hypoglossal-XII: It help in movement of tongue, articulation, swallowing-bolus formation, drawing the head back so as the face is upward by the trapezius nerve, elevation of shoulder by trapezius nerve, flexion of the neck by sternocleidomastoid muscle and rotation of head away from the side of the contracting sternocleidomastoid muscle.

To stimulate cranial nerve involved in speech and swallowing there are some well-established activities like clenching of teeth, opening the jaw against resistance, upper and lower cheek stretch, jaw rotation, side by side anterior cheek stretch, cheek rotation, interior cheek stretch for trigeminal nerve; side by side lip twisting, puffing cheeks, upper posterior cheek stretch, upper and lower lip stretch, lip closure, both the side cheek stretch for facial nerve; tongue tapping for glossopharyngeal nerve; reading task, articulation drill, lower chin rotation for vagus nerve; slugging and upholding, protraction and retraction, elevation and depression is for spinal accessory nerve, pushing tongue against resistance, tongue extension and retraction, side by side tongue movement, tongue push up, tongue pops for hypoglossal nerve; head movement.

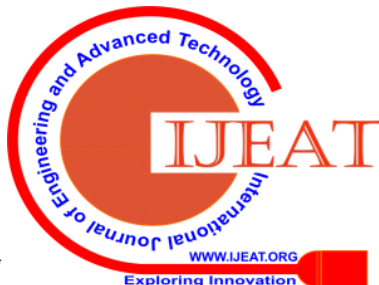


coordinated with eye movements, total body movements and balance tasks, habituation exercises for vestibular system adaptation, relaxation exercises and aerobic dancing for vestibule cochlear nerve.

\section{B. Stage II: Program Strategy for different activities-}

Clenching of Teeth, Opening Jaw against Resistance, Musical games for tongue tapping, Puffing cheeks, Jaw Rotation and side by side lip stretch, Upper and lower cheek stretch, cheek rotation, and upper and posterior cheek stretch, Lip twisting and lip closure are some of the selected activities that are performed and all other including these are given in the table 1 .

\section{Stage III: Validation of selected activities}

The above selected activities are implemented on mild and severely disabled children. We have seen much more improvement in the functional activities of mild and moderately disabled children as compared to the severely disabled children.

Tongue dynamics exercises: In this trial we have taken one mild and one severely disabled child who is unable to produce speech whereas the earlier case was able to produce speech but it was not intelligible to the common person except his family member and people who are in his regular touch. Both the participants are having the same age group of 6-8 years. There is no family history of speech and language disorder in both the cases. The word pronunciation test is done in both Hindi and English language to test articulation skills and to get phonation ability. It has been seen that they were unable to word like 'RAM' and in place of ram they were producing 'LAM'. In the same way they produced 'Lala' in place of 'Mala'. Such types of different word were tested and they were recorded for further analysis. They are having problems in production of $/ \mathrm{t} /, / \mathrm{d} /, / \mathrm{r} /, / \mathrm{j} /$ etc.

Dr. Speech software and hardware systems are installed and connected with a PC is used for analysis purpose with a frame size of 40 frames per second. Audio input sample rate are set at a $22 \mathrm{KHz}$. The microphone and transducer are connected to PC via cable and kept just below the chin of the child.

To overcome all these we have given physical therapy to them for a period of three months of having differentdifferent session structures.

\section{RESULT}

We are focusing on at least two therapeutic activities for each cranial cranial nerve. At present we have selected 15 activities are performed in eight sessions and the result is shown in the given table in terms of lip strength, tongue, loudness, duration and sentence completion.

\begin{tabular}{|l|l|l|l|l|l|l|l|l|}
\hline Sessions & $\mathbf{1}$ & $\mathbf{2}$ & $\mathbf{3}$ & $\mathbf{4}$ & $\mathbf{5}$ & $\mathbf{6}$ & $\mathbf{7}$ & $\mathbf{8}$ \\
\hline Lips (kPa) & 21 & 24 & 21 & 26 & 32 & 33 & 35 & 39 \\
\hline Tongue (kPa) & 56 & 59 & 61 & 57 & 56 & 64 & 61 & 61 \\
\hline $\begin{array}{l}\text { Ah Loudness } \\
\text { (dB SPL) }\end{array}$ & 50 & 48 & 51 & 54 & 57 & 59 & 62 & 63 \\
\hline $\begin{array}{l}\text { Ah } \\
\text { Duration(Sec) }\end{array}$ & 5.0 & 5.4 & 5.0 & 5.6 & 7.1 & 7.8 & 7.1 & 7.4 \\
\hline $\begin{array}{l}\text { Sentences } \\
\text { (dB SPL) }\end{array}$ & 73 & 73 & 74 & 76 & 74 & 74 & 75 & 75 \\
\hline
\end{tabular}

\section{A. Treatment Task Result}

The bar diagram showing the result of therapeutic intervention as the improvement of different parameters as increasing the number of sessions and time elapsed by the patients in different activities.

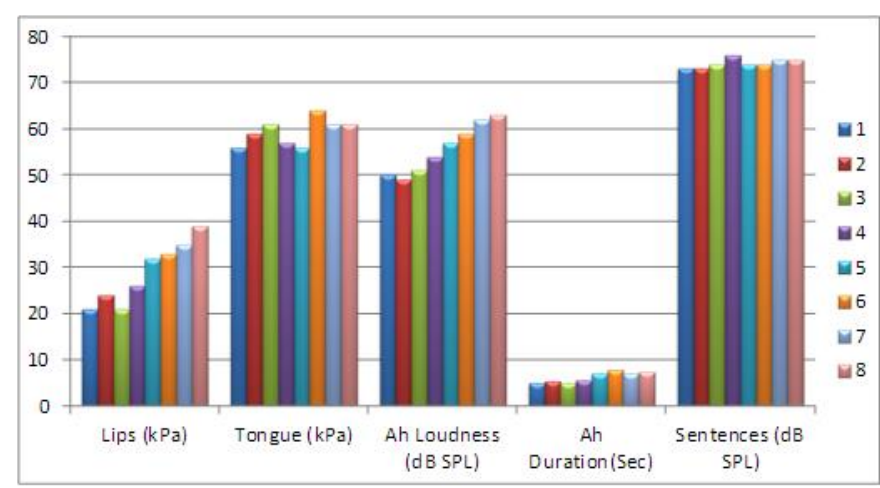

Result of single word intelligibility

\begin{tabular}{|c|c|c|c|c|c|c|c|c|c|}
\hline $\begin{array}{l}\text { List } \\
\text { ener } \\
\text { s }\end{array}$ & 1 & 2 & 3 & 4 & 5 & 6 & 7 & 8 & $\begin{array}{l}\text { Avg } \\
\text { (SD) }\end{array}$ \\
\hline Pre & $\begin{array}{l}2 \\
4 \\
\%\end{array}$ & $\begin{array}{l}2 \\
0 \\
\%\end{array}$ & $\begin{array}{l}3 \\
2 \\
\%\end{array}$ & $\begin{array}{l}2 \\
2 \\
\%\end{array}$ & $\begin{array}{l}2 \\
8 \\
\%\end{array}$ & $\begin{array}{l}2 \\
8 \\
\%\end{array}$ & $\begin{array}{l}3 \\
0 \\
\%\end{array}$ & $\begin{array}{l}1 \\
0 \\
\%\end{array}$ & $\begin{array}{l}24 \% \\
(7 \%)\end{array}$ \\
\hline $\begin{array}{l}\text { Afte } \\
\text { r }\end{array}$ & $\begin{array}{l}6 \\
8 \\
\%\end{array}$ & $\begin{array}{l}7 \\
4 \\
\%\end{array}$ & $\begin{array}{l}7 \\
8 \\
\%\end{array}$ & $\begin{array}{l}7 \\
\mathbf{0} \\
\%\end{array}$ & $\begin{array}{l}6 \\
8 \\
\%\end{array}$ & $\begin{array}{l}7 \\
8 \\
\%\end{array}$ & $\begin{array}{l}7 \\
2 \\
\%\end{array}$ & $\begin{array}{l}7 \\
4 \\
\%\end{array}$ & $\begin{array}{l}73 \% \\
(4 \%)\end{array}$ \\
\hline \multicolumn{10}{|c|}{ Lip and lingual pressure exerted } \\
\hline $\begin{array}{l}\text { Lip } \\
\text { (kPa } \\
\text { ) }\end{array}$ & \multicolumn{3}{|l|}{$\begin{array}{l}27.68 \\
(6.03)\end{array}$} & \multicolumn{3}{|c|}{$\begin{array}{l}45.08 \\
(4.55)\end{array}$} & \multicolumn{3}{|c|}{$\begin{array}{l}34.68 \\
(4.82)\end{array}$} \\
\hline $\begin{array}{l}\text { Lingual } \\
\text { (kPa) }\end{array}$ & & & & & $\begin{array}{l}61.75 \\
(2.75)\end{array}$ & & & $\begin{array}{l}62.10 \\
(1.93)\end{array}$ & \\
\hline
\end{tabular}

\section{CONCLUSION}

We are trying to include more therapeutic activities in curative application of such type of oral motor and speech disorders. The present methodology and treatment procedure can be concluded with the following points:-

Standardization of games with therapeutic application is one of the complex tasks as exposure and intervention.

In our intervention result shows that it is best suited for children as they are unwilling for manual therapy.

We have seen some of the therapeutic activities are more acceptable, enjoyable and engaging to the children.

More exploration and research is needed in this field to make it frequent in professional therapeutic set up and also in occupational therapeutic practices.

Efficacy of gaming therapy must be tested on other parameters like attention, distraction, ease, reliability and emotional expression status.

Therapeutic gaming is promising and need more rigorous research to make it more reliant and effective with better outcome.

Published By:

Blue Eyes Intelligence Engineering \& Sciences Publication 
This technique is having the benefit of less costly, easy to use, reduces frequent visit to hospitals and can be given by direct and indirect ways too.

Therapeutic treatment in form of interactive gaming will improve muscle strength, coordination and motor sensory activities by minimizing muscle spasticity. If all these activities are performed in a regular manner within home premises or in any clinic then it can save the child and disabled. On the other hand it can bring the child and disabled in main streams of living by recovering their muscle strength. Later this can make whole the family happy with the normal and independent living of the child.

Table- I: Activity with impact on motor points and advantage

\begin{tabular}{|c|c|c|c|c|c|}
\hline Nerve & Exercise or activity & Motor points & Advantage & $\begin{array}{l}\text { Type of } \\
\text { Exercise }\end{array}$ & Biofeedback \\
\hline \multirow{8}{*}{$\begin{array}{l}\text { Trigeminal Nerve } \\
\text { Origin: Pons } \\
\text { It is largest cranial nerve of head and } \\
\text { face. It is a kind of mixed nerve i.e. } \\
\text { provides both motor and sensory } \\
\text { function. }\end{array}$} & & & & & \\
\hline & Clenching of teeth & $\begin{array}{l}\text { Masseter, Mandibuler, } \\
\text { Orbicularis Oris }\end{array}$ & Increase oral pressure & Active & Yes \\
\hline & $\begin{array}{l}\text { Opening the jaw } \\
\text { against resistance }\end{array}$ & $\begin{array}{l}\text { Mantalis, } \\
\text { Quadratuslabiiinferioris, } \\
\text { Masseter } \\
\end{array}$ & Improves oral feeding & $\begin{array}{l}\text { Active/Pass } \\
\text { ive }\end{array}$ & Yes \\
\hline & $\begin{array}{l}\text { Upper and lower } \\
\text { cheek stretch }\end{array}$ & Mandibuler and buccal & $\begin{array}{l}\text { Increase range of } \\
\text { motion of jaw, cheeks, } \\
\text { lips and tongue } \\
\end{array}$ & Passive & Yes \\
\hline & Jaw rotation & $\begin{array}{l}\text { Mantalis, } \\
\text { Quadratuslabiiinferioris, } \\
\text { Orbicularis Oris, Masseter and } \\
\text { mandibuler }\end{array}$ & $\begin{array}{l}\text { Improvement in } \\
\text { Mastication }\end{array}$ & Passive & Yes \\
\hline & $\begin{array}{l}\text { Side by side anterior } \\
\text { cheek stretch }\end{array}$ & $\begin{array}{l}\text { Mandibuler, Buccal and } \\
\text { Masseter }\end{array}$ & $\begin{array}{l}\text { Increase muscle } \\
\text { strength }\end{array}$ & Passive & Yes \\
\hline & Cheek rotation & $\begin{array}{l}\text { Trunk, Masseter, Mandibular, } \\
\text { buccal and orbicularis oris }\end{array}$ & $\begin{array}{l}\text { Increase muscle } \\
\text { strength }\end{array}$ & Passive & Yes \\
\hline & $\begin{array}{l}\text { Interior cheek } \\
\text { stretch }\end{array}$ & Quadrature Labiisuperioris & $\begin{array}{l}\text { Improve motion of } \\
\text { vocal cavity }\end{array}$ & Passive & Yes \\
\hline \multirow{6}{*}{$\begin{array}{l}\text { Facial Nerve } \\
\text { Origin: Pons } \\
\text { It controls the muscles of facial } \\
\text { expression. } \\
\text { Function: Sensory and motor }\end{array}$} & $\begin{array}{l}\text { Side by side lip } \\
\text { twisting }\end{array}$ & $\begin{array}{l}\text { Quadrature Labiisuperioris, } \\
\text { Quadratuslabiiinferioris, } \\
\text { orbicularis oris }\end{array}$ & $\begin{array}{l}\text { Able to show facial } \\
\text { expression }\end{array}$ & Passive & Yes \\
\hline & Puffing cheeks & $\begin{array}{l}\text { Trunk, Masseter, Buccal, } \\
\text { Mandibular and orbicularis } \\
\text { oris }\end{array}$ & $\begin{array}{l}\text { Taste sensation and } \\
\text { coordination }\end{array}$ & Active & Yes \\
\hline & $\begin{array}{l}\text { Upper posterior } \\
\text { cheek stretch }\end{array}$ & $\begin{array}{l}\text { Mandibular and orbicularis } \\
\text { oris }\end{array}$ & Muscle strength & Passive & Possibly \\
\hline & $\begin{array}{l}\text { Upper and lower lip } \\
\text { stretch }\end{array}$ & $\begin{array}{l}\text { Quadrature Labiisuperioris, } \\
\text { Quadrature Labiiinfirioris } \\
\text { orbicularis oris }\end{array}$ & do & Passive & Possibly \\
\hline & Lip Closure & $\begin{array}{l}\text { Quadrature Labiisuperioris, } \\
\text { Quadrature Labiiinfirioris and } \\
\text { orbicularis oris }\end{array}$ & & $\begin{array}{l}\text { Active/Pass } \\
\text { ive }\end{array}$ & Yes \\
\hline & $\begin{array}{l}\text { Both the side cheek } \\
\text { stretch }\end{array}$ & $\begin{array}{l}\text { Trunk, Masseter, Buccal, } \\
\text { Mandibular and orbicularis } \\
\text { oris }\end{array}$ & $\begin{array}{l}\text { Increase range of } \\
\text { motion and muscle } \\
\text { strength }\end{array}$ & Passive & Yes \\
\hline $\begin{array}{l}\text { Glossopharyngeal Nerve } \\
\text { Origin: Medulla Oblongata } \\
\text { It innervates the oropharynx carotid } \\
\text { body and sinus, posterior one third of the } \\
\text { tongue, middle ear cavity and } \\
\text { Eustachian tube. } \\
\text { Function: Both(sensory and motor) }\end{array}$ & Tongue tapping & * & $\begin{array}{l}\text { Increases taste } \\
\text { sensation and gag } \\
\text { reflex }\end{array}$ & Passive & Yes \\
\hline \multirow{3}{*}{$\begin{array}{l}\text { Vagus Nerve } \\
\text { Origin: Medulla Oblongata } \\
\text { It has widest distribution in the body } \\
\text { passes through neck and thorax. } \\
\text { Function: Motor and sensory }\end{array}$} & Reading task & * & $\begin{array}{l}\text { Better } \\
\text { understanding }\end{array}$ & Active & Yes \\
\hline & Articulation drill & $*$ & $\begin{array}{l}\text { Increases swallowing } \\
\text { ability }\end{array}$ & Passive & Yes \\
\hline & Lower chin rotation & $*$ & $\begin{array}{l}\text { Improves phonation } \\
\text { and speaking ability }\end{array}$ & Passive & Yes \\
\hline
\end{tabular}




\begin{tabular}{|c|c|c|c|c|c|}
\hline Spinal Accessory Nerve & $\begin{array}{l}\text { Slugging and } \\
\text { upholding }\end{array}$ & $*$ & $\begin{array}{l}\text { Able to move head and } \\
\text { shoulder }\end{array}$ & Active & Possibly \\
\hline \multirow{2}{*}{$\begin{array}{l}\text { Origin: Spinal roots } \\
\text { It has a purely somatic motor function. } \\
\text { Function: Sensory }\end{array}$} & $\begin{array}{l}\text { Protraction and } \\
\text { retraction }\end{array}$ & $*$ & Shoulder movement & Active & Possibly \\
\hline & $\begin{array}{l}\text { Elevation and } \\
\text { depression }\end{array}$ & $*$ & $\begin{array}{l}\text { Head and neck } \\
\text { movement }\end{array}$ & $\begin{array}{l}\text { Passive/Act } \\
\text { ive }\end{array}$ & Possibly \\
\hline \multirow{6}{*}{$\begin{array}{l}\text { Hypoglossal Nerve } \\
\text { Origin: Medulla Oblongata } \\
\text { It innervates the sternocleidomastoid } \\
\text { and trapezius muscles. } \\
\text { Function: Motor and sensory }\end{array}$} & $\begin{array}{l}\text { Pushing tongue } \\
\text { against resistance }\end{array}$ & * & $\begin{array}{l}\text { Increase tongue } \\
\text { strength }\end{array}$ & Passive & Possibly \\
\hline & $\begin{array}{l}\text { Tongue extension } \\
\text { and retraction } \\
\end{array}$ & $*$ & $\begin{array}{l}\text { Increase tongue } \\
\text { movement }\end{array}$ & Active & Possibly \\
\hline & $\begin{array}{l}\text { Tongue side to side } \\
\text { inside }\end{array}$ & $*$ & $\begin{array}{l}\text { Increase tongue } \\
\text { strength and } \\
\text { coordination } \\
\end{array}$ & Active & Possibly \\
\hline & Tongue push up & $*$ & $\begin{array}{l}\text { Increases the strength } \\
\text { back of the tongue }\end{array}$ & Active & Yes \\
\hline & Tongue pops & * & & Active & Possibly \\
\hline & $\begin{array}{l}\text { Tongue push side to } \\
\text { side }\end{array}$ & * & $\begin{array}{l}\text { Increase tongue } \\
\text { strength }\end{array}$ & Active & Possibly \\
\hline \multirow{5}{*}{$\begin{array}{l}\text { Vestibulecochlear Nerve } \\
\text { Origin: } \\
\text { Cerebellopontine angle } \\
\text { It emerges from the pons and exits the } \\
\text { inner skull via the internal acoustic } \\
\text { meatus in the temporal bone. } \\
\text { Function: Sensory }\end{array}$} & $\begin{array}{l}\text { Head movement } \\
\text { coordinated with } \\
\text { eye movements }\end{array}$ & $*$ & $\begin{array}{l}\text { Improve eye } \\
\text { movement }\end{array}$ & $\begin{array}{l}\text { Active/Pass } \\
\text { ive }\end{array}$ & Possibly \\
\hline & $\begin{array}{l}\text { Total body } \\
\text { movements and } \\
\text { balance tasks } \\
\end{array}$ & $*$ & $\begin{array}{l}\text { Balancing and } \\
\text { coordination }\end{array}$ & $\begin{array}{l}\text { Active/Pass } \\
\text { ive }\end{array}$ & Possibly \\
\hline & $\begin{array}{l}\text { Habituation } \\
\text { exercises for } \\
\text { vestibular system } \\
\text { adaptation } \\
\end{array}$ & $*$ & & $\begin{array}{l}\text { Active/Pass } \\
\text { ive }\end{array}$ & Possibly \\
\hline & Relaxation exercises & * & & $\begin{array}{l}\text { Active/Pass } \\
\text { ive }\end{array}$ & Possibly \\
\hline & $\begin{array}{l}\text { Aerobic } \\
\text { dancing/slide and } \\
\text { step program }\end{array}$ & * & $\begin{array}{l}\text { Increases balance and } \\
\text { coordination }\end{array}$ & Active & Possibly \\
\hline
\end{tabular}

Note- * Signifies that the things are under consideration.

\section{REFERENCES}

1. Gauthier LV, Taub E, Perkins C, Ortmann M, Mark VW, Uswatte G. Remodeling the brain plastic structural brain changes produced by different motor therapies after stroke. Stroke; a journal of cerebral circulation. 2008 May;39(5):1520.

2. Fregni F, Pascual-Leone A. Technology insight: noninvasive brain stimulation in neurology - perspectives on the therapeutic potential of rTMS and tDCS. Nature Reviews Neurology. 2007 Jul;3(7):383.

3. Noble KG, Houston SM, Kan E, Sowell ER. Neural correlates of socioeconomic status in the developing human brain. Developmental science. $2012 \mathrm{Jul} ; 15(4): 516-27$.

4. Han S, Pool J, Tran J, Dally W. Learning both weights and connections for efficient neural network. InAdvances in neural information processing systems 2015 (pp. 1135-1143).

5. Jackson A, Zimmermann JB. Neural interfaces for the brain and spinal cord-restoring motor function. Nature Reviews Neurology. 2012 Dec;8(12):690

6. Whitbourne SK. The aging body: Physiological changes and psychological consequences. Springer Science \& Business Media; 2012 Dec 6.

7. Streeter CC, Gerbarg PL, Saper RB, Ciraulo DA, Brown RP. Effects of yoga on the autonomic nervous system, gamma-aminobutyric-acid, and allostasis in epilepsy, depression, and post-traumatic stress disorder. Medical hypotheses. 2012 May 1;78(5):571-9.

8. Senthilkumar k, chandrasekaran kg. Effect of physical combined physical lum yogic practices on selected physical physiological phychological kand performance factors of kabaddi players.

9. Svien LR, Berg P, Stephenson C. Issues in aging with cerebral palsy. Topics in Geriatric Rehabilitation. 2008 Jan 1;24(1):26-40.

10. Braddom RL. Physical Medicine and Rehabilitation E-Book. Elsevier Health Sciences; 2010 Dec 7.

11. Howlin P, Mawhood L, Rutter M. Autism and developmental receptive language disorder-A follow-up comparison in early adult life. II: Social, behavioural, and psychiatric outcomes. The Journal of Child Psychology and Psychiatry and Allied Disciplines. 2000 Jul;41(5):561-78.

12. Sandifer PA, Sutton-Grier AE, Ward BP. Exploring connections among nature, biodiversity, ecosystem services, and human health and well-being: Opportunities to enhance health and biodiversity conservation. Ecosystem services. 2015 Apr 1;12:1-5.

13. Alter MJ. Science of flexibility. Human Kinetics; 2004

14. Carter CW, Micheli LJ. Training the child athlete: physical fitness, health and injury. British journal of sports medicine. 2011 Sep 1; 45(11):880-5.

15. Allec LD, López XH, Porras JB, Ramos RV, del Valle JC, García ÁI Alterations in voice, speech and swallowing in patients with Sjögren's syndrome. Acta Otorrinolaringologica (English Edition). $2011 \mathrm{Ju}$ 1;62(4):255-64.

16. Sohrabi HR, Bates KA, Rodrigues M, Taddei K, Laws SM, Lautenschlager NT, Dhaliwal SS, Johnston AN, Mackay-Sim A, Gandy S, Foster JK. Olfactory dysfunction is associated with subjective memory complaints in community-dwelling elderly individuals. Journal of Alzheimer's Disease. 2009 Jan 1;17(1):135-42.

\section{AUTHORS PROFILE}

Mr. Vinay Kumar Pandey is currently working as Ph.D Research Scholar (CSIR-SRF Fellow) in Department of Biomedical Engineering, North Eastern Hill University, Shillong, Meghalaya India. He completed his maters in VLSI from North Eastern Regional Institute of Science And Technology, Nirjuli, Arunachal Pradesh, and graduated in Electronics and Communication Engineering from Gautum Buddha Technical University Lucknow. I am grateful to my $\mathrm{PhD}$ supervisor Dr. Sudip Paul for inspiring me to do the research in this field.
Published By:

Blue Eyes Intelligence Engineering \& Sciences Publication 


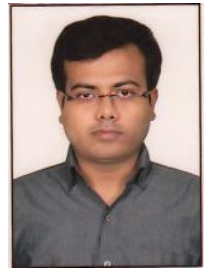

Mr. Vinayak Majhi, is currently working as Junior Research Fellow in IMPRINT-2, a technology development initiative of MHRD and DST in the Department of Biomedical Engineering, NEHU, Shillong. Previously He was working as a Guest Faculty in the Department of Biomedical Engineering, NEHU, Shillong. He completed his B.Tech in Computer Science and Engineering from WBUT, West Bengal, in 2011 and his M. Tech in Computer Science and Engineering from University of Calcutta, West Bengal, India in 2013. Presently he is pursuing his $\mathrm{PhD}$ from Department of Biomedical Engineering, NEHU, Shillong. He is specialized in Computational Biology, Neurodynamics, Neurophysiology, Soft Computing, Software Development, Automation, Bioelectronics. Currently he is working on Automatic Detection of Parkinson's Disease based on Ayurvedic Philosophy.

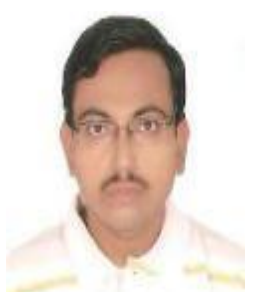

Dr. Sudip Paul: He is currently working as Assistant Professor in the Department of Biomedical Engineering, NEHU, Shillong. He completed his B-Tech in Biomedical Engineering from West Bengal University of Technology, India in 2007 and M-Tech in Biomedical Engineering from Banaras Hindu University, India in 2009. He completed his PhD from IIT (BHU). He has several research papers in reputed journals in the field of Electrophysiology, Biomedical Instrumentation, Biomedical Signal Processing, Artificial Organ and Rehabilitation System.

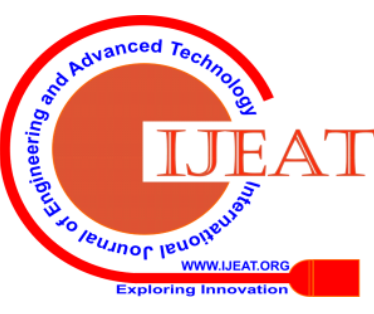

